JOSING: Journal of Nursing and Health

Volume 1, Nomor 1, Desember 2020

e-ISSN: $2745-7877$

p-ISSN: 2746-0851

DOI: https://doi.org/10.31539/josing.v1i1.1149

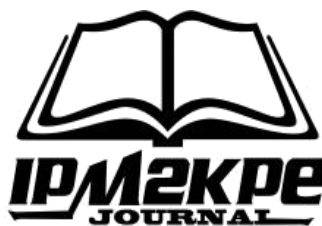

\title{
OBESITY AND HEREDITY FOR DIABETES MELLITUS AMONG ELDERLY
}

\author{
Asih Dewi Setyawati ${ }^{1}$,Thi hai Ly Ngo ${ }^{2}$, Padila ${ }^{3}$, Juli Andri ${ }^{4}$ \\ Muhammadiyah Bengkulu University ${ }^{1,3,4}$ \\ University of Medicine and Pharmacy at Ho Chi Minh City ${ }^{2}$ \\ asihdewi01@gmail.com ${ }^{1}$
}

\begin{abstract}
The study has a purpose to determine obesity and heredity in diabetes mellitus case among elderly in Bengkulu. The method in this study was descriptive correlation design with the total samples were 42 elderly in Primary Health Center calls Sukamerindu, Bengkulu. The data has collected from January until March 2019. The results of unvaried study shows there were 21 people (50\%) of elderly who are obese, 21 people $(50 \%)$ of respondents with heredity, 14 people (33.3\%) with diabetes mellitus. According to the results of chi-square test, it found there was a significant correlation with obesity and genetic factor for diabetic mellitus among elderly in Bengkulu with p-value 0.003 and OR 12.667. In summary, obesity and genetic factors can increase the case of diabetes mellitus among elderly in Primary Health Center, Bengkulu. By giving an enough education and counseling by expert that will reduce the incidence of diabetes mellitus among in Primary health Center Sukamerindu, Bengkulu.
\end{abstract}

Keywords: Diabetes Mellitus, Heredity, Obesity

\section{INTRODUCTION}

Nowadays, various efforts are carried out to realize a healthy, happy, efficient and productive old age for old age. One of them is by living healthy without complaints of disease which means to prolong life in old age (Wahono, 2010). Some of previous researchers found that the greatest proportional increase in the number of people with diabetes mellitus (DM) by age group is expected to occur in people between 60 and 79 years of age. Countries with large adult populations are also those with high numbers of people with diabetes. As a globally, China has the highest number diabetes case with over 109 million adults affected and followed by Muslim countries such as Indonesia as a top seven with 10 million adults affected in 2015 (Cho et al., 2018; Guariguata et al., 2014). Indonesia had an increasing prevalence of diabetes from $1.1 \%$ to $1.5 \%$ in 2013 and it had increase to $2.0 \%$ in 2018 (Balitbangkes, 2018; Santosa et al., 2019).

The risk factors of diabetes include obesity and genetic factor. The number of obese people in Indonesia was $15.4 \%$ in 2013 and in 2018 it increased to $21.8 \%$. Environmental factors and unhealthy lifestyles, such as overeating, fatty food preferences, and a less of physical activity were strong predictors of a risk type 2 diabetes (T2D). The accumulation of fat tissue in the over body mass index (BMI) body might end with the onset of insulin resistance. Insulin resistance makes glucose difficult to enter cells, resulting in increased levels of glucose in the blood causes decrease in hepatic and peripheral insulin sensitivity (Adamiet al., 2016). 
Two types of diabetes, type 1 diabetes is an autoimmune disease that results in complete loss of the insulin-producing $\beta$-cells in the pancreatic cells, while type 2 diabetes (T2D) typically results when insulin secretion from the islets fails to keep pace with increasing insensitivity to the action of circulating insulin on its target tissues (particularly muscle, liver, and fat). The lifetime risk of developing T2D is $40 \%$ for individuals who have one parent with T2D and $70 \%$ if both parents are affected Ali (2013); Ramadhan (2017) which is means people who have parent with diabetes have five times risk of its illness (Trisnawati, Setyorogo, 2013)

According to records of the Bengkulu Provincial Health Office in 2018, it showed diabetes mellitus sufferers in Bengkulu as many as 1,753 patients (Dinkes, 2019). The survey from January to December 2018 found that there were 88 elderly with diabetes in Primary Health Care Sukamerindu, Bengkulu, and 14 elderly from January to March 2019 that reported the total number of diabetes' patient caused by obesity and heredity (PHCS, 2019). Other researcher like Guariguata et al., (2014) found in 2035 the number of diabetes case is expected to increase to 592 people. It is estimated that of the 382 million people, 175 million of them have not been diagnosed, so that the risk of progressive progression into complications is unnoticed and without prevention.

\section{RESEARCH METHOD}

This research was a cross sectional study design with the total sample were 42 elderly in Primary Health Center calls Sukamerindu, Bengkulu. The data has collected from January until March 2019. The sampling technique is using purposive sampling, with inclusion criteria, the elderly who are willing to be respondents, aged 60-80 years, do not have special needs, ability to read and write Bahasa, and provide consent to participate in this study. By using the questionnaire for measure of body scales, the respondent are will explain who is over of BMI and a brief interview will take 5-10 minutes to find out about heredity factor. After returning the questionnaire to the researcher, the calculating calculating, entering the tabulation of the data were began. Data were analyzed by using SPSS version 22. In the descriptive statistic, such as counts and percentage $(\%)$ were using to describe categorical variable. To investigate the factor associated with diabetes, chi-square and pearson's correlation were used in this study.

\section{RESULT}

\section{Univariate Analysis}

Table. 1

Distribution of Obesity, Heredity and Diabetes Mellitus among Elderly $(n=42)$

\begin{tabular}{|c|c|c|c|}
\hline No. & Factor & Frequency $(n)$ & Persentage $(\%)$ \\
\hline \multirow[t]{3}{*}{1.} & Obesity & & \\
\hline & No & 21 & 50 \\
\hline & Yes & 21 & 50 \\
\hline \multirow[t]{3}{*}{2.} & Heredity & & \\
\hline & No & 21 & 50 \\
\hline & Yes & 21 & 50 \\
\hline
\end{tabular}




\begin{tabular}{lcc}
\hline 3. Diabetes Mellitus & \\
No & 28 & 66.7 \\
Yes & 14 & 33.3 \\
\hline Source: Primary data that has been processed (2020)
\end{tabular}

Source: Primary data that has been processed (2020)

Table 1 shows the distribution of obesity, heredity and diabetes mellitus among elderly in Primary Health Care Sumakerindu, Bengkulu with total samples were 42 people. It also presents there were 21 elderly $(50 \%)$ have obesity and heredity factor with 14 elderly (33.3\%) of diabetes mellitus.

\section{Bivariate Analysis}

Table. 2

Differences between Obesity, Heredity and Case of Diabetes Mellitus $(n=42)$

\begin{tabular}{|c|c|c|c|c|c|c|c|}
\hline \multirow{3}{*}{ No. } & \multirow{3}{*}{ Factor } & \multicolumn{4}{|c|}{ Diabetes Mellitus } & \multirow{3}{*}{$\begin{array}{c}\text { OR } \\
(95 \% \mathrm{CI})\end{array}$} & \multirow{3}{*}{$p$-value } \\
\hline & & \multicolumn{2}{|c|}{ Yes } & \multicolumn{2}{|c|}{ No } & & \\
\hline & & $N$ & $\%$ & $N$ & $\%$ & & \\
\hline \multirow[t]{3}{*}{1.} & Obesity & & & & & \multirow{2}{*}{$(2.3-68.9)$} & \multirow[t]{3}{*}{0.003} \\
\hline & No & 2 & 14.3 & 19 & 67.9 & & \\
\hline & Yes & 12 & 85.7 & 9 & 32.1 & 12.667 & \\
\hline \multirow[t]{3}{*}{2.} & Heredity & & & & & \multirow{3}{*}{$\begin{array}{c}(2.3-68.9) \\
12.667\end{array}$} & 0.003 \\
\hline & No & 2 & 14.3 & 19 & 67.9 & & \\
\hline & Yes & 12 & 85.7 & 9 & 32.1 & & \\
\hline
\end{tabular}

Source: Primary data that has been processed (2020)

By using SPSS 22 to analyze pearson correlation coefficients between obesity, heredity and diabetes mellitus, it can be seen that there were significant among variables $(p$-value $=0.003)$. See table 2.

\section{DISCUSSION}

\section{Univariate Analysis}

The data were collected from one of the Primary Health Center Sukamerindu and it is located in Bengkulu by using 42 samples. Half of elderly (50\%) have over of BMI level proven by research by Balitbangkes (2018) which found that the proportion of obesity in adults over 18 years was $21.8 \%$ where Bengkulu province stood at around $20 \%$.

In this study found that more than $50 \%$ of respondents had a history of diabetes mellitus. This is in accordance with previous research conducted in Purwokerto that the of the risk factors of diabetes mellitus is the history of heredity, but it is not yet known if lineage history can accelerate the occurrence of diabetes mellitus in a person (Santosa, et al., 2017). His result showed as much as $21 \%$ of respondents have a history of diabetes mellitus lineage from, $54.9 \%$ of respondents have a history of the lineage of diabetes mellitus from mothers and $23.5 \%$ have a history of diabetes mellitus lineage from father and mother. 
The prevalence of diabetes mellitus increases with age. Research conducted by a researcher in Yogyakarta showed that respondents aged 40-59 years were the most respondents, $52.4 \%$ followed by late adult respondents at $43.5 \%$, data it was found to show that diabetes mellitus is more experienced by people who are middle adulthood and late adulthood (40 years and over) (Ratnaningsih, 2009). According to table 1, this study found that the elderly with diabetes were $33.3 \%$ which means it was lower than the previous research case. However, this study is in line with previous research found that the age group that suffered the most from DM was in the age group 55-59 years as much as $27.67 \%$ (Galadari et al, 2013).

\section{Bivariate Analysis}

This study showed obesity have a significant result with diabetes mellitus. Most of people in Bengkulu, Indonesia had a bad food attitude such as put coconut milk in their food everyday and drink a coffee or tea with a high concentrates of sugar which is it can increase over weight of human body. They often hold or attend party events and serve meat and all sorts of cakes. Respondents loved the meat and often ate it, even eating 1-2 pieces of meat and wrapping it. The respondent disregarded their illness at that time because according to respondents when their blood sugar levels were rising they could drink blood sugar lowering drugs and could re-control the hospital. During the afternoon, the respondents often eat foods such as meatballs, instant noodles, chicken noodles, and fried foods. Respondents in Aceh claimed that the high-speed food is very good, if not used flavorings, the food is not good. In addition, they often eat bread, cakes and biscuits in the morning, afternoon and evening while watching television or chatting with the family or even neighbors. Because the habit of eating those snacks then blood sugar levels increase (Yusnanda et al., 2018).

Independent of body weight, the quality or type of dietary fat and carbohydrates is more crucial than the quantity in determining diabetes risk. Higher consumption of coffee, whole grains, fruits, and nuts is associated with lower risk of diabetes, whereas regular consumption of refined grains, red and processed meats, and sugar-sweetened beverages including fruits juices is associated with increased risk. Dietary patterns rich in fruits and vegetables, whole grains, and nuts and legumes, but lower in red and processed meats, refined grains, and sugar-sweetened beverages are consistently associated with reduced diabetes risk, even after adjustment for body mass index (Korat et al., 2014).

The table 2 also shows people who are over 60 years of age who over weigh have a risk of 12 times to suffer from diabetes compared to the elderly who have a normal body weight. Research in Aceh in 2017 found that there were as many as 23 people (37.7\%) pre-elderly who have more eating habits and 38 people $(62.3 \%)$ pre-elderly who have enough eating habits. Statistical test result with chi-square test obtained pvalue $=<0.001$ means that there is influence of eating habits on the incidence of diabetes mellitus in pre elderly. From the results of analysis also obtained value $(\mathrm{OR}=$ $5.06795 \%$ CI 2,324-11.048) means that the pre-elderly who have a habit of eating more risky 5 times affected by diabetes mellitus with pre-elderly who have adequate eating habits (Yusnanda et al., 2018).

This study showed genetic factor has a significant result with diabetes mellitus. The theory says that a person aged $\geq 45$ years has an increased risk to the occurrence of DM and glucose intolerance because of the degenerative factor that decreases the body function to metabolize glucose (Ramadhan, 2017). However, this condition is not only 
caused by the age factor, but also depends on the length of the sufferer in the condition. Some studies have shown that there is an increase in cases up to age 60 years. The risk for suffering glucose intolerance increases with increasing age. According to Wicaksono (2011) people aged over 45 years old should be conducted Diabetes screening. In this study, people aged $\geq 45$ years are more at risk of getting diabetes compared to people aged $<45$ years. This is in accordance with some epidemiological studies that say that the vulnerability of type-2 Diabetes disease is in line with increasing age.

This study also found elderly who have a history of diabetes from the family will risk 12 times to have the same disease. Other research found that diabetes is a common age-dependent complication of cystic fibrosis (CF) that is strongly influenced by modifier genes (Blackman et al., 2013). A similar result from cross-tabulation result that conducted in 2011 obtained $\mathrm{p}=0,000$ and odds ratio (OR) of 9.3. This indicates that people aged $\geq 45$ years have a risk 9 times for the occurrence of type $2 \mathrm{DM}$ compared to those aged less than 45 years and statistically meaningful (Wicaksono, 2011).

\section{CONCLUSION}

Based on the results of studies that have done can be concluded that there was a influence of obesity and heredity on the incidence of diabetes mellitus. Elderly who have bad eating habits and have a genetic factor were more at risk of suffering from diabetes mellitus.

\section{SUGGESTION}

The advice of researchers for the future of Primary Health Center Sukamerindu, Bengkulu is expected to improve the service optimally, especially in providing a variety of knowledge on how to control blood glucose levels, in conducting counseling and health promotion, doing a healthy life such as explaining the daily diet by providing recommendations in diets of each consuming food that can lead to the incidence of diabetes mellitus in both diabetics and patients who are at any time visiting the way to health care. It expect to the health center in order to make a special prevention for the treatment of diabetes mellitus, so that the sufferer is easier to consult, to reduce the incidence of diabetes mellitus in Primary health Center Sukamerindu, Bengkulu.

\section{REFERENCES}

Adami, G. F., Gradaschi, R., Andraghetti, G., Scopinaro, N., \& Cordera, R. (2016). Serum Leptin and Adiponectin Concentration in Type 2 Diabetes Patients in the Short and Long Term Following Biliopancreatic Diversion. Obesity surgery, 26(10), 2442-2448

Ali, O. (2013). Genetics of Type 2 Diabetes. World journal of diabetes, 4(4), 114

Balitbangkes, K. (2018). Hasil utama Riskesdas 2018: Kementerian Kesehatan RI

Blackman, S. M., Commander, C. W., Watson, C., Arcara, K. M., Strug, L. J., Stonebraker, J. R., . . . Pace, R. G. (2013). Genetic Modifiers of Cystic FibrosisRelated Diabetes. Diabetes, 62(10), 3627-3635

Cho, N., Shaw, J., Karuranga, S., Huang, Y., da Rocha Fernandes, J., Ohlrogge, A., \& Malanda, B. (2018). IDF Diabetes Atlas: Global Estimates of Diabetes Prevalence for 2017 and Projections for 2045. Diabetes Research and Clinical Practice, 138, 271-281

Dinkes. (2019). Dinas Kesehatan Provinsi Bengkulu 
Galadari, S., Rahman, A., Pallichankandy, S., Galadari, A., \& Thayyullathil, F. (2013). Role of Ceramide in Diabetes Mellitus: Evidence and Mechanisms. Lipids in Health and Disease, 12(1), 98

Guariguata, L., Whiting, D. R., Hambleton, I., Beagley, J., Linnenkamp, U., \& Shaw, J. E. (2014). Global Estimates of Diabetes Prevalence for 2013 and Projections for 2035. Diabetes Research and Clinical Practice, 103(2), 137-149

Korat, A. V. A., Willett, W. C., \& Hu, F. B. (2014). Diet, Lifestyle, and Genetic Risk Factors for Type 2 Diabetes: A Review from the Nurses' Health Study, Nurses' Health Study 2, and Health Professionals' Follow-up Study. Current Nutrition Reports, 3(4), 345-354

Ramadhan, M. (2017). Faktor yang Berhubungan dengan Kejadian Diabetes Mellitus di Rsup Dr Wahidin Sudirohusodo dan Rs Universitas Hasanuddin Makassar Tahun 2017: Makassar

Ratnaningsih, A. (2009). Gambaran Tingkat Kepatuhan Menjalani Terapi pada Penderita Diabetes Melitus di Yogyakarta. Jurnal gizi UGM

Santosa, A., Gustiawan, A., Putra, R., \& Chasanah, N. (2019). Body Mass Index to Predict Pre-Diabetes. Ethiopian Journal of Health Development, 33(1)

Santosa, A., Trijayanto, P. A., \& Endiyono, E. (2017). Hubungan Riwayat Garis Keturunan dengan Usia Terdiagnosis Diabetes Melitus Tipe II. URECOL, 1-6

Trisnawati, S. K., \& Setyorogo, S. (2013). Faktor risiko Kejadian Diabetes Melitus Tipe II di Puskesmas Kecamatan Cengkareng Jakarta Barat Tahun 2012. Jurnal Ilmiah Kesehatan, 5(1), 6-11

Wahono, H. (2010). Analisis Faktor-Faktor yang Mempengaruhi Pemanfaatan Posyandu Lansia di Gantungan Makamhaji. Universitas Muhammadiyah Surakarta

Wicaksono, R. P. (2011). Faktor-Faktor yang Berhubungan dengan Kejadian Diabetes Melitus Tipe 2 (Studi Kasus di Poliklinik Penyakit Dalam Rumah Sakit Dr. Kariadi. Faculty of Medicine

Yusnanda, F., Rochadi, R. K., \& Maas, L. T. (2018). Pengaruh Kebiasaan Makan terhadap Kejadian Diabetes Mellitus pada Pra Lansia di BLUD RSU Meuraxa Kota Banda Aceh. Jurnal Muara Sains, Teknologi, Kedokteran dan Ilmu Kesehatan, 1(2), 153-158 